\title{
Consequence of Merger Plan Announcement (Study on Stock Price of State-Owned Islamic Banks)
}

\author{
Hendrik Suhendri* Adrian Junaidar Handayanto Ica Nur Hayani \\ Accounting Program Study, Faculty of Economics, Tribhuwana Tunggadewi University
}

\begin{abstract}
The Covid-19 pandemic has caused the economies of all countries in world to decline sharply. One of sectors affected is the banking industry. The national banking in Indonesia is also affected. The business strategy to make a company can survive in crisis is merger. This study aims to examine changes in stock price of BRI Syariah banks before and at the announcement of planned merger of a State-owned Islamic Banks (SOIB). The samples are daily stock price at closing price within a span of three months before and three months at time of merger plan announcement. The samples are selected by purposive sampling. Based on existing criteria, BRI Syariah was selected as the sample in this study. The data analysis technique used was a parametric test, namely paired sample $\mathrm{t}$-test to test existing hypotheses. The research results show a significant difference or change in stock price of BRI Syariah banks before and at merger plan announcement of SOIB. This is indicated by the $t$ significance value of 0.020 smaller than 0.05 . Thus it can be interpreted that there is a difference in stock price of BRI Syariah Bank before and merger plan announcement of SOIB.
\end{abstract}

Keywords: Merger, SOIB, Stock Price

DOI: $10.7176 /$ RJFA/12-22-08

Publication date: November $30^{\text {th }} 2021$

\section{INTRODUCTION}

The spread of COVID-19 virus has implications for a decrease in global economic activity, including in Indonesia. Several companies suffered losses and closing their businesses. Most difficult companies cannot pay their employees' salaries. Finally, the worst option is employees termination (Putri et al., 2020). The banking or financial services is a business sector in Indonesia that has been affected by the COVID-19 pandemic. The pandemic situation creates three risks for banking industry, namely a decline in asset quality, tightening net interest margins and lower lending (J.P. Morgan in Itsnaini, 2020). One way to maintain the bank financial performance is merger. Merger is a joint of two or more companies into a bigger and stronger company. Therefore we need a voluntary attitude from the joint companies that. These mergers often creates 'companies with new names' (Anderibom, Samuila., Obute, 2015). The Government Regulation of Republic of Indonesia Number 28 of 1999 stated that "a merger is a merger of 2 (two) or more banks, by maintaining the establishment of one bank and dissolving the other banks without first liquidating" (Badan Pemeriksa Keuangan, 1999). Meanwhile, Minister of State-Owned Enterprises (BUMN) Erick Thohir plans to merge three State-owned Islamic Bank (SOIB), namely Bank Mandiri Syariah, Bank BRI Syariah and Bank BNI Syariah to be able to compete in global market (Pratomo, 2020). It should be noted that merger also had a negative impact, including the resignation of several employees due to inconvenience to business orientation, accounting systems and corporate cultures differences (Silalahi \& Ginting, 2020).

Islamic banking as part of national banking industry has tested its business resilience during the financial crises in 1997 and 2008 (Hendrik, 2018). This change in stock price can be used as an indicator of whether the merger has been responded positively or not by the stock market (Tarigan, 2013). This research examines the impact of merger plan announcement on stock price of SOIB. The study focuses on stock prices before and during the merger plan announcement of a SOIB by the Ministry of BUMN.

The BUMN Minister of Erick Thohir said that the main benefit of merger of the three SOIB was the ability to survive from the domino effect of Covid-19. The total assets of SOIB will increase and have great potential to become the leading bank in Indonesia. The largest Muslim population in world should becomes the main market for state-owned Islamic banks (Indonesia, 2020). In addition, Chief Executive of Deposit Insurance Corporation (LPS), Fauzi Ichsan, conveyed several considerations on the importance of SOIB merger (Puspaningtyas, 2020a), namely: (1) Evidently, during the Covid-19 pandemic, Islamic banks could maintain their performance, (2)) The Collection of third party funds, operational costs, financing and capital expenditures can be more efficient, (3) the merged SOIB will be ranked $10^{\text {th }}$ in ranks of National banks with assets reaching 240 trillion, (4). The results of merger have the potential to become the top 10 Islamic banks at global level, (5) The merged bank has a complete and reliable product, (6) The merged bank will become one of backbones of new national economy, (7) The public can access the Islamic financial services easily.

The data from each variable must be tested the normal distribution and normality testing testing the hypothesis (Sugiyono, 2013). The data normality is tested by the Kolmogorof Smirnov. The decision making criteria in normality test are: (1) If the significance value is greater than 0.05 , the data is normally distributed, (2) If the 
significance value is smaller than 0.05 , the data is not normally distributed.

\section{HYPOTHESIS DEVELOPMENT}

Rahman et al. (2018) found the implications of mergers and acquisitions on performance of banking stock prices in Pakistan. Most banks show a decline in stock prices while some banks showed an abnormal positive trend. The results of study Rahman et al. (2018) found that merger and acquisition policies in banking sector in Pakistan will be responded negatively by the capital market. This hypothesis was developed from research (Rahman et al., 2018) in which the current research focuses on finding out the difference in stock price of SOIB before and during the merger plan announcement. Therefore, the research hypothesis is stated below.

$\mathbf{H}_{\mathbf{a}}$ : It is suspected that there is a difference in stock price of BRI Syariah Bank before and at merger plan announcement SOIB.

$\mathbf{H}_{0}$ : It is suspected that there is no difference in stock price of BRI Syariah Bank before and at merger plan announcement of SOIB.

\section{METHOD, DATA, AND ANALYSIS}

This research uses a quantitative method. The research data is numbers and analyzed by statistical tools of SPSS version 24 (Sugiyono, 2013). This research focus is the stock price of State-Owned Islamic Banks (SOIB) listed on Indonesia Stock Exchange. The samples are selected by purposive sampling (Sugiyono, 2016). The criteria for this sample technique are: (1) SOIB, (2) listed in Indonesia Stock Exchange (IDX), (3) Not a subsidiary or equivalent Business Unit which the financial statements are integrated with the parent company. Based on these criteria, only BRI Syariah fulfills the criteria. On other hand, Bank Syariah Mandiri and Bank BNI Syariah have not yet gone public but have gone private, automatically not listed on Indonesia Stock Exchange (IDX). In addition, these two banks are respectively subsidiaries of Bank Mandiri and Bank BNI.

This research uses secondary data which contains the closing stock price. The closing price data for stocks used are stock price data for three months prior the merger plan announcement and three months at time of merger plan announcement of SOIB.

\section{RESULTS}

Table 1 shows results of descriptive statistical calculations from stock price data before and at time of merger plan announcement of SOIB. The stock price prior the announcement of merger was IDR 657,1000 and stock price at time of merger plan announcement was IDR 1,421,0000. The data used are from the 3 months before and 3 months at time of merger plan announcement of SOIB. If we look at table 1, there is an increase in stock prices at time of merger plan announcement of SOIB.

\section{Table 1. Descriptive Statistics}

\begin{tabular}{llllrrr} 
& & Mean & N & Std. Deviation & Std. Error Mean \\
\hline Pair 1 & $\begin{array}{l}\text { Before merger plan } \\
\text { announcement }\end{array}$ & 657,1000 & 3 & 199,93947 & 115,43511 \\
\cline { 2 - 7 } & At merger plan announcement & 1421,0000 & 3 & 376,78259 & 217,53553
\end{tabular}

The paired sample t-test data must has normal distribution. This study examine the normal distribution by normality test. Table 2 shows the Kolmogorov-Smirnov test results showed that sign value before the merger was 0.934 greater than 0.05 . It can be interpreted that the data has normal distribution. Table 2 also shows that at time of merger the significance value is 0.470 is greater than 0.05 . It means that data used is also has normal distribution. Tabel 2. Tests of Normality

\begin{tabular}{lr|r|r|r|r|r} 
& \multicolumn{3}{c}{ Kolmogorov-Smirnov $^{\mathrm{a}}$} & \multicolumn{3}{c}{ Shapiro-Wilk } \\
& Statistic & df & Sig. & Statistic & df & Sig. \\
\hline Before merger plan announcement &, 183 & 3 &. &, 999 & 3 &, 934 \\
\hline At merger plan announcement &, 291 & 3 &. &, 925 & 3 &, 470 \\
\hline
\end{tabular}

a. Significance Correction

Table 3 below shows the results of Paired sample t-test on stock price of BRI Syariah Bank before and at merger plan announcement of SOIB. In table, it can be seen that significance value is 0.020 . This significance result is less than 0.05 . This significance value shows that $\mathrm{Ha}$ is accepted and $\mathrm{H} 0$ is rejected. It shows a difference in stock price of BRI Syariah Bank before and at merger plan announcement of SOIB. 
Tabel 3. Uji Paired Sample t-Test

\begin{tabular}{|c|c|c|c|c|c|c|c|c|c|}
\hline \multicolumn{10}{|c|}{ Paired Samples Test } \\
\hline & & \multicolumn{5}{|c|}{ Paired Differences } & \multirow[b]{3}{*}{$\mathrm{t}$} & \multirow[b]{3}{*}{ df } & \multirow{3}{*}{$\begin{array}{l}\text { Sig. (2- } \\
\text { tailed) }\end{array}$} \\
\hline & & \multirow[b]{2}{*}{ Mean } & \multirow{2}{*}{$\begin{array}{c}\text { Std. } \\
\text { Deviation }\end{array}$} & \multirow{2}{*}{$\begin{array}{l}\text { Std. Error } \\
\text { Mean }\end{array}$} & \multicolumn{2}{|c|}{$\begin{array}{c}95 \% \text { Confidence } \\
\text { Interval of Difference }\end{array}$} & & & \\
\hline & & & & & Lower & Upper & & & \\
\hline \multirow[t]{2}{*}{$\begin{array}{l}\text { Pair } \\
1\end{array}$} & $\begin{array}{l}\text { Before merger plan } \\
\text { announcement }\end{array}$ & - & 188,91730 & 109,07145 & & & $-7,004$ & 2 & ,020 \\
\hline & $\begin{array}{l}\text { At merger plan } \\
\text { announcement }\end{array}$ & 763,900 & & & 1233,19659 & 294,60341 & & & \\
\hline
\end{tabular}

\section{DISCUSSION}

The results of Paired Sample $t$ test show that the merger plan announcement of SOIB has a significant effect on changes in stock prices at BRI Syariah Bank. It can be interpreted that merger plan announcement of SOIB increase the stock price of BRI Syariah Bank since the merger plan announcement. The results of Paired Sample t Test contradict to the results of Rahman et al. (2018) which examined the impact of merger on banks in Pakistan. In fact, the banking merger received a negative response from the stock market in Pakistan. This is evidenced by the decline in banking stock prices in Pakistan.

The increase in stock prices due to the merger plan announcement of SOIB is consistent with the news on Warta Ekonomi news page, the trading of BRI Syariah stocks from 15 October 2020 was at highest level, namely IDR 1,690 per stock (Nurfitriyani, 2020; Anwar, 2020). The increase in stock prices relates with merger plan announcement of SOIB, namely PT Bank BRI Syariah, PT Bank Syariah Mandiri (BSM) and PT Bank BNI Syariah (BNIS). Once combined, the total assets of SOIB will reach IDR 214.6 Trillion with a core capital of more than IDR 20.4 Trillion (Nurfitriyani, 2020).

CNBC Indonesia news page was stated that stock price of PT Bank BRI Syariah Tbk (BRIS) soared to reach the Upper Auto Reject (ARA) level for two consecutive days, namely on Tuesday and Wednesday. Auto rejection is a lower and upper limit of an increase and decrease in stock prices within one trading day on exchange. The purpose of Auto rejection implementation is to make fair stock trading (mncsekuritas.id). The stocks of BRI Syariah Bank increased are 56\% (14/10/2020). This is because there is a plan to merge Islamic banks into one entity. The MoU or Memorandum of Understanding (Conditional Merger Agreement / CMA) stated that the three banks and their respective holding companies were signed on Tuesday (13/10/2020). It has been determined that in this merger, Bank BRI Syariah becomes a surviving bank or entity that receives the merger (surviving entity) from the merger of the three SOIB (Putra, 2020)

Fika Nurul Ulya also conveyed to Kompas.com that stock price of BRI Syariah banks increased in first trade, Tuesday (13/10/2020). This condition made foreign investors buy up stocks of BRI Syariah Bank as a survivor bank of merger process of three SOIB. After the merger becomes effective, BRI Syariah bank will become the surviving entity and stockholders of BNI Syariah and Bank Mandiri Syariah will become the stockholders of entity that accepts the merger.

Puspaningtiyas reporter also conveyed to Republika.co.id that since the planned merger of a SOIB, at opening of trading (06/07/2020) BRI Syariah Bank stocks experienced a quite rapid increase of 18.24\%. M. Nafan Aji Gusta Utama, a Binaartha Sekuritas analyst, said that the increase was due to news that BRI Syariah would be merged with two other SOIB. Nafan also conveyed that the increase in stock prices showed a positive market response to the planned merger. The merger itself will strengthen the capital structure and increasing the company value. This condition will increase public confidence in company and can increase employee loyalty at Bank BRI Syariah, which in 2018 was the first Islamic bank to list its stocks in Indonesian Stock Exchange (IDX) (Puspaningtyas,2020).

Bank BRI Syariah was included in top list of top gainers after the merger plan announcement. The data from the Indonesia Stock Exchange show that the stocks with BRIS code have increased by $25 \%$ to level 430 (Setiawan, 2020) . Herry Gunardi, Head of Project Management Office (PMO) Team and Deputy Director of Bank Mandiri, stated that signing of CMA was the initial part of merger process. It was further explained that the merger of three SOIB is predicted to open up great potential to become the 10 leading Islamic banks in world. (Hardjanti, 2020).

The merger is the latest breakthrough in history of Islamic banking. This will provide fresh air for all parties. This becomes opportunity for stock players to have the stock price of BRI Syariah as survival, because in long term this stock has a bright prospect (Hardjanti, 2020).

The opening of stock trading on Tuesday (13/10/2020) shows the stocks of PT Bank BRI Syariah Tbk (BRIS) increased significantly, even touching the price of IDR 1.125 per stock. Compared to the previous day's trading closing, the stocks of this subsidiary of PT Bank Rakyat Indonesia Tbk (BBRI) have strengthened by up to $25 \%$. 
The total transaction value is IDR 335.94 billion, 23,957 times and a volume of 317.76 million units of stocks, it was recorded at around 10.16 AM. Foreign investors were also recorded to have bought with a net value of IDR 4.77 billion in regular market. The increase in BRI Sharia stocks in the day's trading (13/10/2020) was consistent with the clarity of merger plan or better known as the merger plan of SOIB (Aldin, 2020).

Ma'ruf Amin, Vice President of Republic of Indonesia, said that merger could potentially generate total assets of IDR 390 trillion in 2025. The joining of three Islamic Banks at this early stage means that new Sharia Bank will have assets of around IDR 225 trillion, with 1,200 offices branches that spread to all corners of country. Ma'ruf Amin also explained that development of Islamic Financial Industry is one of government's focuses in developing the 'halal industry' in Indonesia. This new Islamic bank should operate in February 2021, the merger of these three Islamic banks is a big step and merger process has started, namely by signing a Conditional Merger Agreement (CMA)(Anwar, 2020).

\section{CONCLUSION AND SUGGESTION}

This study aims to determine changes in stock price of BRI Syariah banks before the and at merger plan announcement of SOIB. Based on results of Paired Sample t Test, it is shown that there is a difference in stock price of BRI Syariah banks before and at the merger plan announcement of SOIB. This means that stock price of BRI Syariah banks has increased when the government announced the planned merger of SOIB. This is differ with previous research where the banking merger was actually responded negatively by the capital market. This limitation is only uses comparison study, therefore further studies should use different analytical tools to make more complex analysis. In addition, further research should add other variables, such as volume of stock trading and extending the research period to improve the generalizability of the research results.

\section{REFERENCES}

Aldin, I. U. (2020). Merger Bank Syariah BUMN Makin Terang, Saham BRI Syariah Naik 25\%. katadata.co.id. Anderibom, Asauten Samuila., Obute, C. O. (2015). THE EFFECTS OF MERGERS AND ACQUISITIONS ON PERFORMANCEOF COMMERCIAL BANKS IN NIGERIA : Evidenced from United Bank for Africa ( UBA ) plc BY Obute, Christopher O . Ph . D Economics Department, Benue State University, MakurdiNigeria Email : coobute@. International Journal of Education and Research, 3(4), 93-112.

Anwar, M. C. (2020). Ma'ruf Amin: Merger 3 Bank Syariah Jadikan RI Pemain Global. CNBC Indonesia.

Badan Pemeriksa Keuangan, I. (1999). Merger, Konsolidasi Dan Akuisisi Bank. https://peraturan.bpk.go.id/Home/Details/54282

Hardjanti, R. (2020). Kilas Balik Saham BRIS, Baru 2 Tahun Melantai tapi Bikin Takjub. OKEZONE TV.

Hendrik, S. (2018). RJOAS, 6(78), June 2018. 6(June), 197-205.

Indonesia, C. (2020). Erick Thohir Ungkap Alasan Merger 3 Bank Syariah BUMN. CNN Indonesia. https://www.cnnindonesia.com/ekonomi/20201013165129-78-557962/erick-thohir-ungkap-alasan-merger3-bank-syariah-bumn

Itsnaini, m. ja'far shiddiqsunariya S. . dan putri raudhatul. (2020). Dampak Covid-19 terhadap Lembaga Keuangan Syariah (PERBANKAN SYARIAH). 1-17.

Nurfitriyani, A. (2020). Terus Turun, Investor Tuh Salah Banget Kalau Lepas Saham BRI Syariah. Warta Ekonomi.

Tarigan, Pivi Princifal Yosefa, W. A. P. (2013). analisis dampak merger dan akuisisi terhadap abnormal return dan kinerja keuangan pada perusahaan yang terdaftar di bursa efek Indonesia. Journal of Chemical Information and Modeling, 53(1), 1689-1699.

Pratomo, M. N. (2020). Merger Bank Syariah BUMN, Erick Thohir: Jadi Sekaliber Bank Globa. Bisnis.com.

Puspaningtyas, L. (2020a). 7 Alasan Pentingnya Merger Bank Syariah BUMN. Republika.Co.Id. https://republika.co.id/berita/qi6gay440/7-alasan-merger-bank-syariah-milik-bumn

Puspaningtyas, L. (2020b). Wacana Merger, Saham BRI Syariah Naik 18 Persen. REPUBLIKA. co,id.

Putra, T. (2020). Masya Allah, Ini Prospek Gokil Saham BRI Syariah Pascamerger. CNBC Indonesia.

Putri, R. K., Sari, R. I., Wahyuningsih, R., \& Meikhati, E. (2020). Angka Phk Terhadap Penurunan. 1(1), 50-55.

Rahman, Z., Ali, A., \& Jebran, K. (2018). The effects of mergers and acquisitions on stock price behavior in banking sector of Pakistan. Journal of Finance and Data Science, 4(1), 44-54. https://doi.org/10.1016/j.jfds.2017.11.005

Setiawan, K. (2020). Saham BRI Syariah Naik 25 Persen Pasca Pengumuman Merger. Bisnis.Tempo.Co. https://bisnis.tempo.co/read/1395629/saham-bri-syariah-naik-25-persen-pasca-pengumuman-merger

Silalahi, K., \& Ginting, C. (2020). Analisis Perbedaan Kinerja Keuangan Perusahaan Sebelum dan Setelah Merger (Studi Pada Bank CIMB Niaga Yang Terdaftar Di BEI). Jurnal Manajemen, 6, 35-46.

Sugiyono. (2013). Metode Penelitian Kuantitatif-Kualitatif dan R\&D (18th ed.). Penerbit Alfabeta.

Sugiyono. (2016). Metode Penelitian Kuantitatif dan R\&B. Alfabet. 